\title{
Effects of two different deep digital flexor tenotomy techniques on distal articular angles of equine cadaver forelimbs
}

\author{
Efeito de duas técnicas de tenotomia do flexor digital profundo sobre os ângulos articulares distais \\ dos membros anteriores de equinos: estudo post-mortem
}

\author{
Antonio Cezar de Oliveira Dearo ${ }^{\mathrm{I}}$ Vitor Bruno Bianconi Rosa ${ }^{\mathrm{II}}$ Peter Reichmann ${ }^{\mathrm{I}}$ \\ Milton Luis Ribeiro de Oliveira ${ }^{\mathrm{I}}$
}

\begin{abstract}
Deep digital flexor (DDF) tenotomy is a technique employed for years to treat selected disorders of the musculoskeletal system in horses. Although two different surgical approaches (i.e. mid-metacarpal and pastern) have been described for performing the procedure, in vitro quantitative data regarding the modifications induced by either technique on the distal articular angles is lacking. Therefore, the purpose of the study reported here was to investigate the viability of a proposed biomechanical system of induced-traction used to compare the two DDF tenotomy techniques by measuring the distal articular angles of equine cadaver forelimbs. Ten pairs of forelimbs were collected and mounted to a biomechanical system developed to apply traction at the toe level. Dorsal articular angles of the metacarpophalangeal (MP), proximal interphalangeal (PIP) and distal interphalangeal (DIP) joints were determined by geometric lines on radiographs taken before and after performing each technique. Comparisons between each tenotomy group and its own control, for each joint, and between the two tenotomy groups using as variable the difference between the tenotomy and control groups were tested. Despite the lack of statistical significance, the DDF tenotomy technique at the pastern level produced extension, to a lesser and greater extent, of the PIP and DIP joints, respectively when compared to the mid-metacarpal level. No remarkable differences could be observed for the MP joint. The developed traction-induced biomechanical construct seemed to be effective in producing valuable quantitative estimations of the distal articular angles of equine cadaver forelimbs subjected to different DDF tenotomy techniques.
\end{abstract}

Key words: laminitis, flexural deformity, tendon, joint, horse.

\section{RESUMO}

A tenotomia do flexor digital profundo (FDP) é uma das técnicas cirúrgicas empregadas para o tratamento de algumas anormalidades osteomusculares, como as deformidades flexurais e a laminite em equinos. Embora diferentes acessos cirúrgicos (i.e. terço médio do metacarpo e quartela) possam ser utilizados, informações quantitativas obtidas in vitro, referentes aos ângulos articulares distais estabelecidos após a execução de ambos os acessos não são conhecidas. Dessa forma, o objetivo deste trabalho foi estudar a viabilidade de um sistema biomecânico de tração induzida na comparação de duas técnicas de tenotomia do FDP por meio da mensuração dos ângulos articulares distais em peças anatômicas de equinos. Dez pares de membros anteriores foram coletados e montados em um sistema biomecânico de tração induzida aplicada na região da pinça do casco. Os ângulos articulares dorsais das articulações metacarpo falangeana (MF), interfalangeana proximal (IFP) e interfalangeana distal (IFD) foram determinados através de linhas geométricas traçadas com base no exame radiográfico realizado antes $e$ após a realização de cada técnica. Comparações entre cada técnica e seu respectivo controle, para cada articulação, e entre as duas técnicas, utilizando as diferenças angulares obtidas antes e após cada técnica, foram testadas. Embora não se tenha obtido diferença estatisticamente significativa, a técnica de tenotomia do FDP ao nível da quartela produziu um maior e menor grau de extensão das articulações IFD $e$ IFP, respectivamente, quando comparado à técnica no terço médio do metacarpo. Diferenças inexpressivas foram observadas na articulação MF. O sistema biomecânico de tração induzida se mostrou eficiente na determinação quantitativa dos valores aproximados das angulações articulares distais de membros anteriores de equinos submetidos às duas técnicas de tenotomia do FDP.

Palavras-chave: laminite, deformidade flexural, tendão, articulação, equino.

IDepartamento de Clínicas Veterinárias, Centro de Ciências Agrárias (CCA), Universidade Estadual de Londrina (UEL), CP 6001, 86051-990, Londrina, PR, Brasil. E-mail: dearoaco@uel.br. Autor para correspondência.

IIPrograma de Residência em Clínica Médica, Cirúrgica e Reprodução de Grandes Animais, UEL, Londrina, PR, Brasil. 


\section{INTRODUCTION}

Developmental orthopaedic disease (DOD) and conditions involving the foot are important causes of permanent conformational faults or lameness in horses (KING \& MANSMANN, 1997). Among them, flexural limb deformities or 'contracted tendons' and laminitis play an important role in the equine industry scenario not only because of their high morbidity in the equine population but the guarded prognosis for the horse to develop a successful athletic carrier, especially when selected surgical techniques are used as treatment.

A technique employed for years to treat flexural limb deformities of the distal interphalangeal joint as well as laminitis is the radical section of the deep digital flexor tendon (DDFT) (FACKELMAN et al., 1983). Two different surgical approaches have been described for performing the procedure. In the first one, the DDFT is exteriorized and severed at the midmetacarpal level (ADAMS \& FESSLER, 2000). In the second one, the tendon is exteriorized and severed following opening of the tendon sheath at the midpastern level (FACKELMAN et al., 1983). Apart from the advantages and disadvantages inherent to each technique, immediate and sometimes unwanted effects (e.g. hyperextension) are produced by the radical section of the tendon (HUNT et al., 1991; FACKELMAN et al., 1983; KRAMER, 2006). Although clinical observations have suggested that 'release of the tendon' to a greater extent is produced by the pastern technique (HUNT et al., 1991; HUNT, 2003), quantitative data regarding the distal conformational modifications induced by either technique is lacking.

One of the difficulties encountered to study the tenotomy's effects in live and healthy animals is the ethical and animal welfare considerations related to the crippling nature of the technique. In order to overcome these issues, biomechanical systems capable of generating forces applied to the limb using ex-vivo specimens have been successfully developed allowing extrapolations of the results to clinical situations (BUKOWIECKI et al., 1987; SHOEMAKER et al., 1991; ALEXANDER et al., 2001). To the authors' knowledge, controlled studies comparing the effects of both techniques using biomechanical models have not been described.

Therefore, the purpose of the present study was to investigate the viability of a proposed biomechanical system of induced-traction used to compare the two deep digital flexor tenotomy techniques currently employed in clinical practice by measuring the distal articular angles of equine cadaver forelimbs. The tested hypothesis was that the pastern technique would produce a greater 'release of the tendon' when compared to the mid-metacarpal technique.

\section{MATERIAL AND METHODS}

Procedures were performed in cadaver forelimbs of horses that were euthanatized for reasons unrelated to the project or died in the premises of the Veterinary Teaching Hospital of the State University of Londrina, Paraná, Brazil. Pairs of forelimbs from 10 mixed breed horses, aged 8 months to 12 years, with no signs of musculoskeletal disorders were collected immediately after death and frozen at $-20^{\circ} \mathrm{C}$ until the time of testing. Body weight ranged approximately from 280 to $500 \mathrm{~kg}$. The entire forelimb, from the scapula to the foot, was used. Following complete thawing at room temperature, limbs were transversally drilled at selected sites and secured with their medial aspect facing down to a $180 \mathrm{~cm}$ x $30 \mathrm{~cm}$ x $2.5 \mathrm{~cm}$ wooden platform by means of $7 \mathrm{~mm}$, full threaded bolts with nuts and washers. Bolts were placed at the proximal and distal aspect of the third metacarpal bone, proximal radius and proximal scapula allowing free movement of the hoof and distal joints. An approximately $5 \mathrm{~cm} \mathrm{x} 5 \mathrm{~cm} \mathrm{x}$ $2 \mathrm{~cm}$ drilled wooden block was interposed between the medial aspect of the limb and the platform at screw sites to allow slight elevation of the limb from the platform. A round, full threaded, $8 \mathrm{~cm}$ long, $5 \mathrm{~mm} \varnothing$ screw hook was perpendicularly drilled to the distal aspect of the hoof wall at midline (toe level) and fixed at the sole aspect with a nut and washer. On the dorsal aspect of the limb a digital scale was connected to the screw hook. The opposite extremity of the scale was connected to a $2 \mathrm{~mm} \varnothing$ steel cable positioned parallel to the limb axis up to a turnbuckle attached to the top of the platform (Figure 1). A 20kg tension was applied to the system by adjusting the turnbuckle. A radiographic exam (lateromedial projections) of the metacarpophalangeal (MP), proximal interphalangeal (PIP) and distal interphalangeal (DIP) joints was performed and the articular angulations were determined by geometric lines traced along the longitudinal axis of each bone as described by HUSSNI (1991). Briefly, the longitudinal axes (bisecting lines) of the third metacarpal bone, proximal and middle phalanx were drawn by a line uniting two midpoints on the diaphyses of each bone. The longitudinal axis of the distal phalanx was drawn by a line traced parallel to its dorsal surface. The dorsal angles formed by the intersected lines were measured with the aid of a protractor. The experimental model was designed for each limb to act as its own control. Therefore, angles 


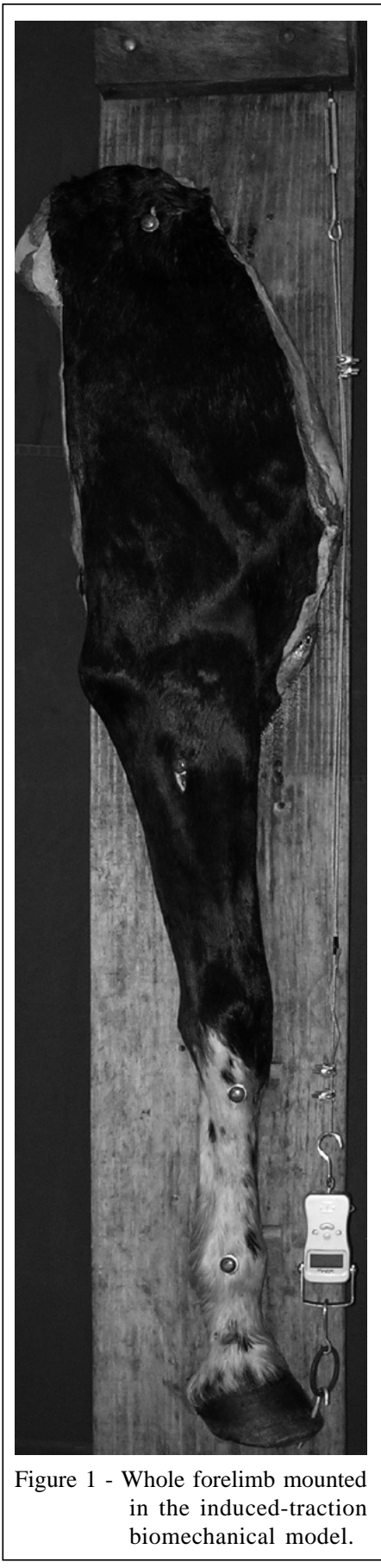

i n i t i a 1 l y obtained from the limbs were assigned to a control group. Once the initial radiographic exam was concluded, the tension on the turnbuckle was released and one of the two deep digital flexor tenotomy techniques (i.e. mid-metacarpal or pastern) was randomly (coin toss) selected and performed according to FACKELMAN et al. (1983) and ADAMS \& F E S S L E R $\left(\begin{array}{llll}2 & 0 & 0 & 0\end{array}\right)$, respectively. Shortly, for the mid-metacarpal technique, a 4 c m longitudinal skin incision was made over the lateral aspect of the DDFT followed by blunt dissection of the tendon. The DDFT was exteriorized and transversally

severed. For the pastern technique, a $4 \mathrm{~cm}$ longitudinal skin incision was made on the palmar aspect of the pastern, the tendon sheath was incised and the DDFT was transversally severed. Once the technique was completed, the same tension was reapplied to the system and a second radiographic exam was performed. Measurements of the dorsal joint angles were repeated as previously described. The second technique was performed on the remainder limb of the pair following the same procedures previously described. Angles obtained from the limbs subjected to the mid-metacarpal technique were designated as "metacarpal tenotomy (mc)" group. Similarly, angles obtained from the limbs subjected to the pastern technique were designated as "pastern tenotomy (p)" group. The author responsible for measuring the angles on radiographs was unaware of the employed technique.

Data were analyzed using Minitab for Windows (Minitab Inc. USA). Normality of data was assessed by the Ryan-Joiner (similar to Shapiro-Wilk) normality test. For each joint, comparisons between each tenotomy group and its own control group were analyzed by the Student t-test for pairwise samples. Comparisons between the two tenotomy groups were analyzed by the Student t-test using as variable the difference between the tenotomy and control groups. The significance level of the test was set at 0.05 .

\section{RESULTS AND DISCUSSION}

Assembly of the induced-traction construct didn't present any difficulty. The whole limb, from the scapula to the hoof, was used to preserve all proximal attachments of the deep digital flexor muscle (i.e. medial umeral epicondile, medial aspect of the olecranon, caudal aspect of the radius and small portion of the ulna) (SISSON, 1981) and its anatomical relationship with adjacent muscle groups.

Significant differences $(\mathrm{P} \leq 0.01)$ between control and tenotomy groups regardless of the technique employed were noticed for each joint. The dorsal articular angles of the MP and DIP joints decreased to a greater extent when compared to the PIP joint (Table 1). Primary stability of PIP joint is provided by two short collateral ligaments and four palmar ligaments (KAINER, 2002). The reason the dorsal articular angle of the PIP joint decreased to a lesser extent may be explained by the strong stability of the joint provided by the palmar support structures other than the DDFT. As previously stated, overextension of the PIP joint is prevented by its palmar (axial and abaxial) ligaments, the straight sesamoidean ligament as it inserts on the scutum medium and the SDFT (DENOIX, 1994) through its insertions on the distal and proximal extremities of the proximal and middle phalanx, respectively (SISSON, 1981; KAINER, 2002).

The dorsal MP joint angle was the most affected by the DDF tenotomy. Differences up to 23 degrees could be observed between control and tenotomy groups (Table 1). In clinically normal horses, when joints are loaded in axial compression during the weightbearing position, deep digital flexor tenotomy 
Table 1 - Descriptive statistics of joint angles (in degrees) of equine cadaver forelimbs subjected to different DDF tenotomy techniques in an induced-traction construct.

\begin{tabular}{|c|c|c|c|c|c|c|c|c|c|c|}
\hline \multirow[t]{3}{*}{ Measure } & \multirow[t]{3}{*}{ Technique } & \multicolumn{3}{|c|}{ Control group } & \multicolumn{3}{|c|}{ Tenotomy group } & \multicolumn{3}{|c|}{ Differences (Control - Tenotomy) } \\
\hline & & & & & & -Joints & --- & & & --- \\
\hline & & MP & PIP & DIP & MP & PIP & DIP & MP & PIP & DIP \\
\hline \multirow[t]{2}{*}{ Mean } & $\mathrm{mc}$ & 171.2 & 166 & 159.7 & 157.6 & 163.3 & 154 & 13.6 & 2.7 & 5.7 \\
\hline & $\mathrm{p}$ & 172.2 & 166.1 & 160.6 & 158.7 & 163.2 & 151.1 & 13.5 & 3.0 & 9.5 \\
\hline \multirow[t]{2}{*}{ SEM } & $\mathrm{mc}$ & 0.57 & 1.39 & 1.34 & 1.27 & 1.0 & 1.09 & 1.02 & 0.83 & 0.86 \\
\hline & $\mathrm{p}$ & 1.41 & 0.94 & 1.77 & 1.41 & 0.57 & 1.18 & 1.69 & 0.76 & 1.85 \\
\hline \multirow[t]{2}{*}{ SD } & $\mathrm{mc}$ & 1.81 & 4.40 & 4.24 & 4.01 & 3.16 & 3.43 & 3.24 & 2.63 & 2.71 \\
\hline & $\mathrm{p}$ & 4.47 & 2.96 & 5.58 & 4.47 & 1.81 & 3.73 & 5.36 & 2.40 & 5.84 \\
\hline
\end{tabular}

MP = Metacarpophalangeal

PIP = Proximal interphalangeal

DIP = Distal interphalangeal

$\mathrm{SD}=$ Standard deviation

$\mathrm{SEM}=$ Standard error of the mean mc $=$ Mid-metacarpal $\mathrm{p}=$ Pastern has its greatest effects over the DIP joint angulation (HUSSNI, 1991). The loading pattern underwent by the limbs in the present study was developed by upward tension at the toe level. When modifications of the toe or heel angle are experimentally induced in live horses or in isolated limbs, corresponding modifications occurs on distal joint angulations and on tension of the flexor tendons and suspensory apparatus (DENOIX, 1994; RIEMERSMA et al., 1996; CREVIERDENOIX et al., 2001). Elevation of the toe results in DIP joint extension with increased tension on the DDFT and its accessory ligament, straightened up of the pastern and increased dorsal MP angle. Furthermore, participation of the SL and SDFT in supporting the fetlock is decreased (Denoix, 1985, 1987 apud DENOIX, 1994). Although the toes of the control limbs used in this experiment were not intentionally tensioned to a point of rotating upward $\left(\right.$ mean DIP angle $=159.7^{\circ}$ ), the tension used (i.e. 20kg) might have caused a certain degree of toe elevation, especially in the specimens taken from lighter horses. This observation is supported by the DIP joint angle (mean \pm sd $=$ $171.6^{\circ} \pm 5.99$ ) described in 20 normal horses (HUSSNI, 1991). In these horses, the mean \pm sd MP joint angle was $154.27 \pm 6.5$ (HUSSNI, 1991). Therefore, the increased dorsal MP angle induced by traction at the toe (mean $\pm \mathrm{sd}=171.7 \pm 3.36$ ) might have played a central role in the angular differences of the MP joint between clinically normal horses and the specimens used in the experiment reported here.

Comparisons between the pastern and the mid-metacarpal technique didn't show any statistical significance for any joint. The lack of statistical difference was probably due to the small sample size (power $=0.307$ ). Thus, a larger sample size should have been used to result in significant differences between groups. Despite the lack of statistical difference, the pastern technique has produced extension of the DIP joint to a greater extent when compared to the midmetacarpal technique (Figure 2), confirming the clinical impression. It has been reported that the magnitude of tension release provided by the pastern technique is greater when compared to the mid-metacarpal technique. Tendon ends may separate 6 to $10 \mathrm{~cm}$ after transection in the pastern region (HUNT, 2003). Although separation between the transected tendon ends was not measured in this study, the overall results are in agreement with the observations reported by HUNT (2003). According to his observations, this greater release would be achieved because of the close proximity of the surgical region to the insertion of the DDFT on the distal phalanx and unrestricted movement within the deep flexor tendon sheath. In contrast, separation after mid-metacarpal tenotomy would be restricted by peritenon attachment to the subcutaneous tissue (HUNT, 2003; PARKS \& O’GRADY, 2003). An alternative hypothesis to explain the lesser tendon release produced by the mid-metacarpal technique would be the greater compression sustained by the distal segment of the DDFT at the fetlock joint after transection. The increased fetlock extension produced by the DDF tenotomy, which has been demonstrated in this study and elsewhere (HUSSNI, 1991), would create increased dorso-palmar pressure over the DDFT 


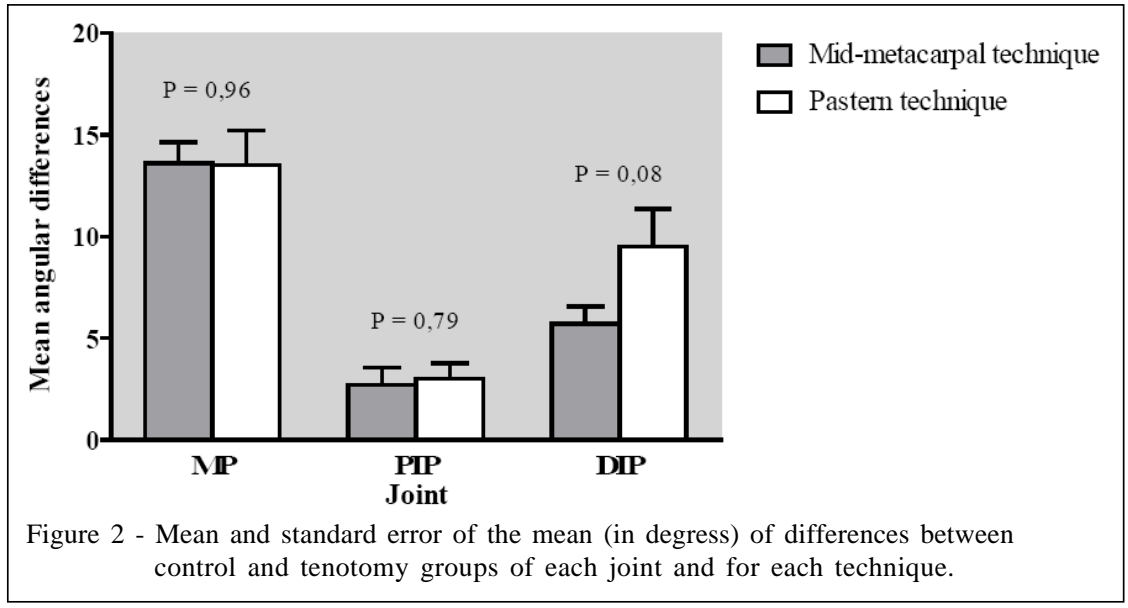

against the SDFT. At this level, both flexor tendons are palmarly surrounded by the inelastic, strong, transverse fibers of the palmar annular ligament, which in association with the proximal scutum (i.e. proximal sesamoid bones and intersesamoidean ligament) form a real canal (DENOIX, 1994). The resultant increase in transverse compression at the fetlock level over the distal segment of the transected DDFT would ultimately restrict its distal excursion. The lesser the distal excursion of the distal DDFT segment, the lesser the DIP joint extension.

One of the disadvantages of the deep digital flexor tenotomy technique regardless of what region it is performed is a variable degree of digital hyperextension (HUNT et al., 1991; FACKELMAN et al., 1983; KRAMER, 2006) that can occur following the procedure. Based on the results of this study and the degree of contracture of the distal interphalangeal joint observed in a given horse, it is possible that digital hyperextension can be null or produced to a lesser extent when the deep digital flexor tenotomy is performed at the mid-metacarpal level. Grounds for this though are supported by a study comparing the effects of the deep digital flexor tenotomy performed proximal and distal to the insertion of the inferior check ligament on the DDFT on normal horses. Out of 10 horses, in which the procedure was performed at the midmetacarpal level distad to the insertion of the inferior check ligament, hyperextension was observed permanently in 3 horses, only at walk in 4 horses and only at a trot in 3 horses (HUSSNI, 1991).

Interestingly, the greater extension produced in the DIP joint by the pastern technique was not uniformly observed in all joints. A slight increase in extension of the MP joint produced by the mid-metacarpal technique was noted when compared to the pastern technique. Again, this difference could have been more reliable if a larger sample size had been used.

Although the construct used in this experiment to compare the two deep digital flexor tenotomy techniques has provided valuable estimations regarding the quantitative differences of distal joint angulations between both techniques, the study is not exempt from limitations. Similarly to other biological variables, measurement of joint angles radiographically represented by the longitudinal axes of bones composing a joint is a variable amenable to imprecision. Although it has been used and validated in previous experimental studies (BUSHE et al., 1987; HUSSNI, 1991), small variations in joint angulations, particularly due to a slight degree of obliqueness of the radiographs (BUSHE et al., 1987) should not be unexpected.

The idea behind the development of the traction-induced biomechanical system was based upon the ethical and animal welfare considerations related to the crippling nature of the technique. Although the system has not been able or developed to reproduce the pattern of loading or conditions observed in clinical situations, it is believed that good estimations of the distal joints angle range can be obtained by it when tenotomy or even other selected corrective techniques (e.g. desmotomy) are performed in clinical patients. A system that could mimic a more realistic scenario of forces such as one mounted exerting axial compression forces from top to bottom of the limb rather than applying traction on its distal aspect should provide more precise information.

In conclusion, the DDF tenotomy technique at the pastern level performed in cadaver forelimbs subjected to a traction-induced biomechanical system didn't produce statistically significant differences on the distal joint angles when compared to the mid- 
metacarpal level. The lack of statistical difference is probably related to the small sample size. From the clinical standpoint, these results emphasize the need of a proper case selection before indication of either technique.

\section{ACKNOWLEDGMENTS}

The authors would like to thank the radiology technician Mr. Antonio Ribeiro Guimarães for performing the radiographic exams, the State University of Londrina Universidade Estadual de Londrina - for the undergraduate scholarship in science (PROIC - UEL) and the Araucaria Foundation - Fundação Araucária (Apoio ao Desenvolvimento Científico e Tecnológico do Paraná) - for funding the project.

\section{REFERENCES}

ADAMS, S.B.; FESSLER, J.F. Deep digital flexor tenotomy. In: _. Atlas of equine surgery. Philadelphia: Saunders, 2000. Cap.73, p.359-361.

ALEXANDER, G.R. et al. Effects of superior check desmotomy on flexor tendon and suspensory ligament strain in equine cadaver limbs. Veterinary Surgery, v.30, p.522-527, 2001. Available from: <http://onlinelibrary.wiley.com/doi/10.1111/ vsu.1991.20.issue-1/issuetoc $>$. Accessed: August 3rd, 2011. doi: 10.1111/j.1532-950X.1991.tb00300.x.

BUSHE, T. et al. The effect of hoof angle on coffin, pastern and fetlock joint angles. Proceedings of the American Association of Equine Practitioners, v.33, p.729-737, 1987. Available from: <http://agris.fao.org/agris-search/search/ display.do?f=1989/US/US89513.xml;US8843016>. Accessed: August $3^{\text {rd, } 2011 .}$

BUKOWIECKI, C.F. et al. In vitro strength of the suspensory apparatus in training and resting horses. Veterinary Surgery, v.16, p.126-130, 1987. Available from: <http:// onlinelibrary.wiley.com/doi/10.1111/vsu.1987.16.issue-2/ issuetoc $>$. Accessed: August $3^{\text {rd }}$, 2011. doi: 10.1111/j.1532950X.1987.tb00923.x.

CREVIER-DENOIX, N. et al. Effects of heel and toe elevation upon the digital joint angles in the standing horse. Equine Veterinary Journal, v.33, Suppl.33, p.74-78, 2001. Available from: <http://onlinelibrary.wiley.com/doi/10.1111/ evj.2001.33.issue-S33/issuetoc>. Accessed: August $3^{\text {rd }}, 2011$. doi: 10.1111/j.2042-3306.2001.tb05364.x.

DENOIX, J.M. Functional anatomy of tendons and ligaments in the distal limbs (manus and pes). Veterinary Clinics of North America: Equine Practice, v.10, n.2, p.273-322, 1994. Available from: <http://www.ncbi.nlm.nih.gov/pubmed/ 7987720>. Accessed: August 4th, 2011.
FACKELMAN, G.E. et al. Surgical treatment of severe flexural deformities of the distal interphalangeal joint in young horses. Journal of the American Veterinary Medical Association, v.182, p.949952, 1983. Available from: <http://www.ncbi.nlm.nih.gov/pubmed/ 6682845>. Accessed: August 4 $4^{\text {th }}, 2011$.

HUNT, R.J. et al. Mid-metacarpal deep digital flexor tenotomy in the management of refractory laminitis in horses. Veterinary Surgery, v.20, n.1, p.15-20, 1991. Available from: <http:// www.ncbi.nlm.nih.gov/pubmed/2008769>. Accessed: August $4^{\text {th }}$, 2011.

HUNT, R.J. Laminitis. In: ROSS, M.W.; DYSON, S.J. Diagnosis and Management of lameness in the horse. Philadelphia: Saunders, 2003. Cap.35, p.325-339.

HUSSNI, C.A. Tenotomia do músculo flexor digital profundo proximal à inserção do ligamento acessório: proposta de uma nova técnica cirúrgica em equinos e seu efeito sobre os ângulos das articulações metacarpofalangeana e interfalangeanas. 1991. 37f. Dissertação (Mestrado em Medicina Veterinária) - curso de Pós-graduação em clínica: fisiopatologia médica, FMVZ, Unesp, Botucatu, SP.

KAINER, R.A. Functional anatomy of equine locomotor organs. In: Stashak, T.S. Adams' lameness in horses. 5.ed. Philadelphia: Lippincott Williams \& Wilkins, 2002. Cap.1, p.1-72.

KING, C.; MANSMANN, R. Disease process and their management. In: Equine lameness. Grand Prairie: Equine Research, 1997. p. 553-609.

KRAMER, J. Deep digital flexor tenotomy. In: Wilson, D. et al. Manual of equine field surgery. St. Louis: Saunders Elsevier, 2006. Cap.16, p.98-102.

PARKS, A.; O'GRADY, S.E. Chronic laminitis: current treatment strategies. Veterinary Clinics of North America: Equine Practice, v.19, p.393-416, 2003. Available from: <http:// www.ncbi.nlm.nih.gov/pubmed/14575166>. Accessed: August $4^{\text {th }}, 2011$.

RIEMERSMA, D.J. et al. Influence of shoeing on ground reaction forces and tendon strains in the forelimbs of ponies. Equine Veterinary Journal, v.28, n.2, p.126-132, 1996. Available from: <http://onlinelibrary.wiley.com/doi/10.1111/ j.2042-3306.1996.tb01604.x/pdf>. Accessed: August 4 ${ }^{\text {th }}, 2011$. doi: 10.1111/j.2042-3306.1996.tb01604.x.

SHOEMAKER, R.S. et al. Desmotomy of the accessory ligament of the superficial digital flexor muscle in equine cadaver limbs. Veterinary Surgery, v.20, n.4, p.245-252, 1991. Available from: <http://www.ncbi.nlm.nih.gov/pubmed/1949561>. Accessed: August $4^{\text {th }}, 2011$.

SISSON, S. Músculos do equino. In: GETTY, R. Anatomia dos animais domésticos. 5.ed. Rio de Janeiro: Interamericana, 1981. Cap.17, p.350-423. 